\title{
Retinoblastoma cT1a TNM Finding v8
}

National Cancer Institute

\section{Source}

National Cancer Institute. Retinoblastoma cT1a TNM Finding v8. NCI Thesaurus. Code C140686.

Tumors $3 \mathrm{~mm}$ or less and further than $1.5 \mathrm{~mm}$ from disc and fovea. (from AJCC 8th Ed.) 